\title{
Acute transverse myelitis and intramedullary spinal cord tumors in children - clinical presentation, differential diagnosis and prognostic factors
}

\section{Ostre poprzeczne zapalenie rdzenia kręgowego oraz guzy śródrdzeniowe u dzieci - obraz kliniczny, diagnostyka różnicowa, czynniki prognostyczne}

\author{
Ilona Kopyta', Marek Mandera², Beata Wesolek-Kaminska', Joanna Sordyl³, Ryszard Sordyl${ }^{4}$, Beata \\ Sarecka-Hujar ${ }^{5}$, Michal Skrzypek ${ }^{6}$ \\ ${ }^{1}$ Department of Pediatrics and Developmental Age Neurology, Chair of Pediatrics, School of Medicine in Katowice, Medical \\ University of Silesia, Poland \\ ${ }^{2}$ Department of Pediatric Neurosurgery, School of Public Health in Bytom, Medical University of Silesia, Poland \\ ${ }^{3}$ Department of Pediatrics and Pediatric Endocrinology, School of Medicine in Katowice, Medical University of Silesia, Poland \\ ${ }^{4}$ Department of Neurosurgery', School of Medicine in Katowice, Medical University of Silesia, Poland; Department of \\ Neurosurgery², School of Medicine in Katowice, Medical University of Silesia, Poland \\ ${ }^{5}$ Department of Drug Technology, School of Pharmacy with the Division of Laboratory Medicine in Sosnowiec, Medical \\ University of Silesia, Poland \\ ${ }^{6}$ Department of Biostatistics, School of Public Health in Bytom, Medical University of Silesia, Poland
}

DOI:10.20966/chn.2017.52.391

\section{STRESZCZENIE}

Cel: Scharakteryzowanie przebiegu klinicznego oraz czynników prognostycznych ostrego poprzecznego zapalenia rdzenia kregowego (acute transverse myelitis - ATM) oraz guzów śródrdzeniowych (intramedullary spinal cord tumors - ISCTs) u dzieci. Materiał i metody: Badana grupa składała się z 11 dzieci z ATM oraz 22 pacjentów z ISCTs, hospitalizowanych w Oddziale Neurologii Dziecięcej oraz Oddziale Neurochirurgii Dziecięcej w ciągu ostatnich 10 lat. U wszystkich pacjentów przeprowadzono badanie neurologiczne oraz badanie MRI. U dzieci, u których podejrzewano ATM, dodatkowo wykonano analizy płynu mózgowo-rdzeniowego. Badanie kontrolne wykonano po średnio 50 miesiącach w przypadku dzieci z ATM i średnio po 55 miesiącach w ISCTs. Wyniki: Dzieci w obu grupach prezentowały podobne objawy, jednak zaburzenia czucia były częstsze w grupie pacjentów z ATM. Płeć, wiek oraz średnia liczba zajętych segmentów rdzenia kręgowego nie wpływały znamiennie na wyniki w badaniu kontrolnym w obu grupach. Większość dzieci z ATM, które nie prezentowały objawów w badaniu kontrolnym, cechowała dobra odpowiedź na wstępne leczenie steroidami. Wnioski: Ze względu na podobny obraz kliniczny, zarówno ATM jak i ISCTs powinny być rozważane podczas diagnostyki różnicowej zaburzeń z zakresu rdzenia kręgowego. Zaburzenia czucia wydają się być bardziej specyficzne dla ATM. Dobra odpowiedź na wstępne leczenie steroidami u dzieci z ATM powinna być brana pod uwagę jako korzystny czynnik rokowniczy.

Słowa kluczowe: poprzeczne zapalenie rdzenia kręgowego, guzy rdzenia kręgowego, dzieci, zapalenie
ABSTRACT

Purpose: To characterize the clinical course, outcomes and prognostic factors of acute transverse myelitis (ATM) and intramedullary spinal cord tumors (ISCTs) in children. Methods: The studied group consisted of 11 children with ATM and 22 children with ISCTs, hospitalized in the Departments of Pediatric Neurology and Pediatric Neurosurgery in the last 10 years. The patients underwent a neurological examination and MRI. CSF analyses were performed in children with a suspicion of ATM. Follow up lasted about 50 months in the ATM and 55 months in ISCTs. Results: Patients in both groups presented similar symptoms. A sensory loss was most common in the group of ATM children. Sex, age and the mean number of injured segments presented no significant influence on the results in the follow up in both groups. Most of the ATM children with no residual symptoms presented a good response to the initial steroid therapy. Conclusions: Because of similar symptoms both ATM and ISCTs should be taken into account in differential diagnosis of spinal cord disturbances. Sensory loss seems to be more specific for the ATM. A good response to the initial steroid treatment in the group of ATM children could be considered as a positive prognostic factor.

Key words: transverse myelitis, spinal cord tumor, children, inflammation

\section{INTRODUCTION}

Neurological disorders affecting the spinal cord in children very often pose a diagnostic challenge - a correct and quick diagnosis can determine the most appropriate treatment and give hope for a good clinical outcome. Acute transverse myelitis and intramedullary spinal cord tumors are diseases with uncharacteristic clinical symptoms and doubtful prognosis of recovery. The differential diagnosis includes inter alia, vascular lesions, demyelinating diseases, spinal cord traumas and diseases of vertebral structures (e.g. Paget disease) [1] .

Acute transverse myelitis is a rare neurologic syndrome caused by focal inflammation of the spinal cord [2-6]. Ac- 
cording to American data there are about 1400 new cases of ATM reported per year [7-8]. The disease has no sexual and familial preference $[2,9,10]$. About $20 \%$ of ATM cases occur in patients under 18 years of age [7-8]. The etiopathogenesis of ATM is heterogeneous. Possible causes include infections, vascular and autoimmunological factors $[3,4,6,8,11]$. It could also occur as a manifestation of demyelinating and paraneoplastic disorders but according to literature about 10 to $45 \%$ of all ATM cases are idiopathic [7, 10-12]. Because of the unclear pathophysiology of ATM, no selective therapy has been available for this disease up to now. Corticosteroids [5,8], plasmapheresis $[8,13]$, cyclophosphamide [5] or immunotherapy are the most commonly applied treatments.

ISCTs in children are rare neoplasms of the central nervous system (about $5 \%$ of all CNS tumors and $35-40 \%$ of spinal cord tumors). There are about 1-2.6 new reported cases per one million children) [14-20]. ISCTs may cause uncharacteristic symptoms or even remain asymptomatic for a long time [19-21]. Surgical treatment plays a major role in the treatment of patients with ISCTs, in some cases followed by radiation therapy of the tumor site $[16,17$, 19-23]. It is usually difficult to distinguish ISCTs and ATM clinically. Lumbar puncture and MRI constitute an important part of the differential diagnosis [1-19, 21, 22, 24, 25].

\section{AIM}

The aim of our study was to characterize the clinical course of ATM and ISCTs and to establish prognostic predictors of these diseases in children.

\section{METHOD}

The studied population consisted of 11 patients with the diagnosis of transverse myelitis and 22 patients with intramedullary spinal cord tumors out of over 20400 children admitted to the Department of Pediatrics and Developmental Age Neurology and the Department of Pediatric Neurosurgery in the years 2001-2011.

The ATM group consisted of 3 girls and 8 boys, while in the group of children with ISCT the ratio of boys to girls was 17:5. The average age of diagnosis was 12 years for children with ATM and 10 years for patients with ISCTs.

The follow up examinations lasted from 3 months to 10 years from the ATM onset (mean 50 months) and on average 55 months from the diagnosis of ISCT.

\section{DIAGNOSIS}

The diagnosis of ATM was established according to uniform diagnostic criteria and nosology for ATM proposed by Transverse Myelitis Consortium Working Group [2]. As per the recommendations, all of the patients underwent physical and neurological examinations, a cerebrospinal fluid analysis including the evaluation of the oligoclonal immunoglobulin of the IgG class as well as electrophysiological tests and a magnetic resonance imaging (MRI) [3]. Spinal and brain MRIs were performed using a $1.5 \mathrm{~T}$ magnets (GE Healthcare). In addition, in order to detect other possible etiological factors, some microbiological and serological tests were performed.
The diagnosis of ISCT was based on a neurological examination and MRI performed using a $1.5 \mathrm{~T}$ magnets (GE Helthcare).

\section{TREATMENT}

Steroids and/or immunoglobulin were administered to all of the patients with ATM. Some individuals received an empirical antibacterial, antiviral or antifungal therapy. Additionally, rehabilitation treatment was continuously performed from the early stage of the disease.

Surgical treatment in patients with ISCTs was performed under standard microsurgical conditions. Conventional laminectomy was performed in cases of concomitant spinal stenosis. Laminotomy was chosen when there were no contraindications to reconstruct the spinal canal. The extent of surgical treatment was divided into three groups: total, subtotal and partial.

\section{STATISTICAL ANALYSES}

All statistical analyses were performed using SAS version 9.4 (SAS Institute, Inc., Cary, NC, USA). The normality of distribution of quantitative data (age) was evaluated by the Shapiro-Wilk W test and for the homogeneity of the variance the Levene test was used. Associations between numerical variables were assessed by the Student's t-test or the Mann-Whitney U test when indicated, and the Fisher test was used for qualitative data. Because the outcome was observed in the same individual multiple times under different conditions, we analyzed the data using logistic regression for repeated measurers, with group, gender, and age as explanatory variables. The aim of it was to assess whether there was a significant change in the prevalence of each outcome measure (motor dysfunction, sphincters disorders, sensory disturbances) at the beginning of the study and during the follow-up. The Fisher's exact test was used to analyze whether there is a relation between the results of histopathological analysis and the condition of the patient at the follow-up. The McNemar's test and the Cohen's kappa coefficient were used to compare each patient's condition at the beginning and at the follow-up. The Spearman's correlation coefficient was used to analyze if the number of affected segments was related to the results of the follow-up examination. Statistical significance was accepted at $\mathrm{p}<0.05$.

\section{RESULTS}

Table 1 shows general characteristics of the analyzed patients. The distribution of sex was similar in both analyzed groups with ATM and spinal cord tumor. Patients with ATM were slightly older than patients with spinal cord tumor (tab. I).

\section{ONSET}

The onset of ATM was sudden in most patients. Some circumstances preceding the disease could be pointed out in four cases. Six patients noticed some uncharacteristic prodromal symptoms including, most commonly, back pain or numbness and lower limb pain or paresthesia.

Contrary to the acute course of ATM, some uncharacteristic clinical signs of ISCTs usually occurred months befo- 
Tabela I. General characteristics of the patients with ATM and ISCTs.

Tabla I. Ogólna charakterystyka pacjentów z ATM oraz ISCTs

\begin{tabular}{|c|c|c|c|}
\hline & $\begin{array}{l}\text { All patients } \\
\mathrm{n}=33\end{array}$ & $\begin{array}{l}\text { ATM } \\
\mathrm{n}=11\end{array}$ & $\begin{array}{l}\text { Spinal cord tumor } \\
\mathbf{n}=\mathbf{2 2}\end{array}$ \\
\hline $\operatorname{Sex}(n, \%)$ & $\begin{array}{l}q n=8(24.2) \\
+n=25(75.8) \\
3 n=10\end{array}$ & $\begin{array}{l}9 \mathrm{n}=3(27.3) \\
O \mathrm{n}=8(72.7)\end{array}$ & $\begin{array}{l}q n=5(22.7) \\
+n=17(77.3) \\
3 n=10\end{array}$ \\
\hline $\begin{array}{l}\text { Age (mean } \pm S D ; \\
\text { Median, min-max) }\end{array}$ & $\begin{array}{l}10.73 \pm 5.30 \\
10.67(1.00-17.25)\end{array}$ & $\begin{array}{l}12.09 \pm 4.95 \\
14.00(1.00-17.00)\end{array}$ & $\begin{array}{l}10.04 \pm 5.45 \\
9.71(1.42-17.25)\end{array}$ \\
\hline $\begin{array}{l}\text { Number of affected segments } \\
\text { (mean } \pm \text { SD) }\end{array}$ & $6.27 \pm 4.37$ & $8.64 \pm 6.39$ & $5.09 \pm 2.31$ \\
\hline $\begin{array}{l}\text { The degree of resection } \\
\text { totalis }(n, \%) \\
\text { subtotalis }(n, \%) \\
\text { partialis }(n, \%)\end{array}$ & $\begin{array}{l}7,31.8 \\
12,54.6 \\
3,13.6\end{array}$ & $\begin{array}{l}- \\
- \\
-\end{array}$ & $\begin{array}{l}7,31.8 \\
12,54.6 \\
3,13.6\end{array}$ \\
\hline
\end{tabular}

re the diagnosis (mean time: 36.2 months). Patients usually reported back pain and limb paresis. Sphincter disorders, muscular atrophy and spinal cord deformity were less common signs of the early stage of ISCT.

\section{SYMPTOMS DURING HOSPITALIZATION}

Three main groups of neurological symptoms were itemized: motor dysfunction, dysesthesia and sphincters disorders.

Lower limb flaccid paresis or paralysis was observed in all patients with ATM, but there was a variation of the affected region. Additionally, in 5 out of 11 patients it was accompanied by upper limb paresis as a result of inflammatory process in the cervical segments of the spinal cord. Neurological examination performed during the first hospitalization revealed paresis or paralysis in $70 \%$ of children with ISCTs. In addition, there were some cases of spastic paresis or paralysis in this group. Motor symptoms were asymmetric in similar percentages of patients in both diseases.

Dysesthesia was the second most common symptom in both ATM and ISCTs. More than $72 \%$ of patients suffering from ATM presented signs of dysesthesia, but the range of affected area did not always correlate with the level of spine injury observed in the MRI. In the group of ISCTs children sensory loss was present in lower percentage (30\%) (statistical significance, $\mathrm{p}=0.023$ ) and was consistent with affected regions of the spinal cord.

The sphincters disorders, urine and/or stool retention or incontinence were less common symptoms observed in both groups of patients. This disturbance was observed in more than $63 \%$ of children with ATM and only $10 \%$ of patients with ISCTs.

Additionally, a quite numerous group of symptoms, including deformity and disturbances in spinal cord mobility, occurred only in children with ISCTs (25\%).

\section{MRI FINDINGS}

In all cases of ATM, the MRI examination revealed inflammatory changes in the spinal cord. In one patient pathologically intensive signals laterally to the putamen were observed as well. The injury level varied in wide range: from $\mathrm{C} 3$ to medullary cone. Neuroimaging re- vealed pathological signals especially in thoracic segments or in both thoracic and cervical regions ( 9 out of 11 cases).

The MRI examination performed in the group of children with ISCTs demonstrated tumors located in different parts of the spinal cord. ISCTs most commonly injured lumbar segments or the border between cervical and thoracic part of the spinal cord. In 4 cases the neoplasm was accompanied by syringomyelia or syringobulbia.

Both, ATM and ISCTs were characterized by a long segment involvement (mean 8.64 segments vs. 5.09, respectively) (Fig. 1, Fig. 2).

\section{CSF EXAMINATION}

In the group of children with ATM, the signs of inflammation in the cerebrospinal fluid were observed in five patients, but the pleocytosis and/or concentration of proteins were, most commonly, only slightly increased. In six cases the CSF examination revealed no pathological changes. CSF oligoclonal IgG bands were examined in three cases but with no evidence of their presence. The bacteriological cultures of the blood and CSF were negative in all patients with ATM. The serological tests for the diagnosis of bacterial or viral infections were negative in most of the subjects. In two cases the outcomes of the Mycoplasma pneumoniae and/or HSV blood serological tests in the IgG immunoglobulin class were doubtful.

\section{TREATMENT}

The treatment was complex in most patients with ATM. Children received a combined therapy which depending on clinical state of the individual included: steroids (Dexamethasone, Prednisone or Methylprednisolone) administrated simultaneously or alternately with immunoglobulin, antibiotics, antiviral or antifungal medicines. The length of hospital stay was 17-143 days (on average 45 days).

Surgical treatment was performed in all patients with the diagnosis of ISCT. For the surgical approach 10 children underwent osteoplastic laminotomy and 13 underwent conventional laminectomy. Complete resection of the tumor was achieved in nearly $32 \%$ (7 patients). Most patients 

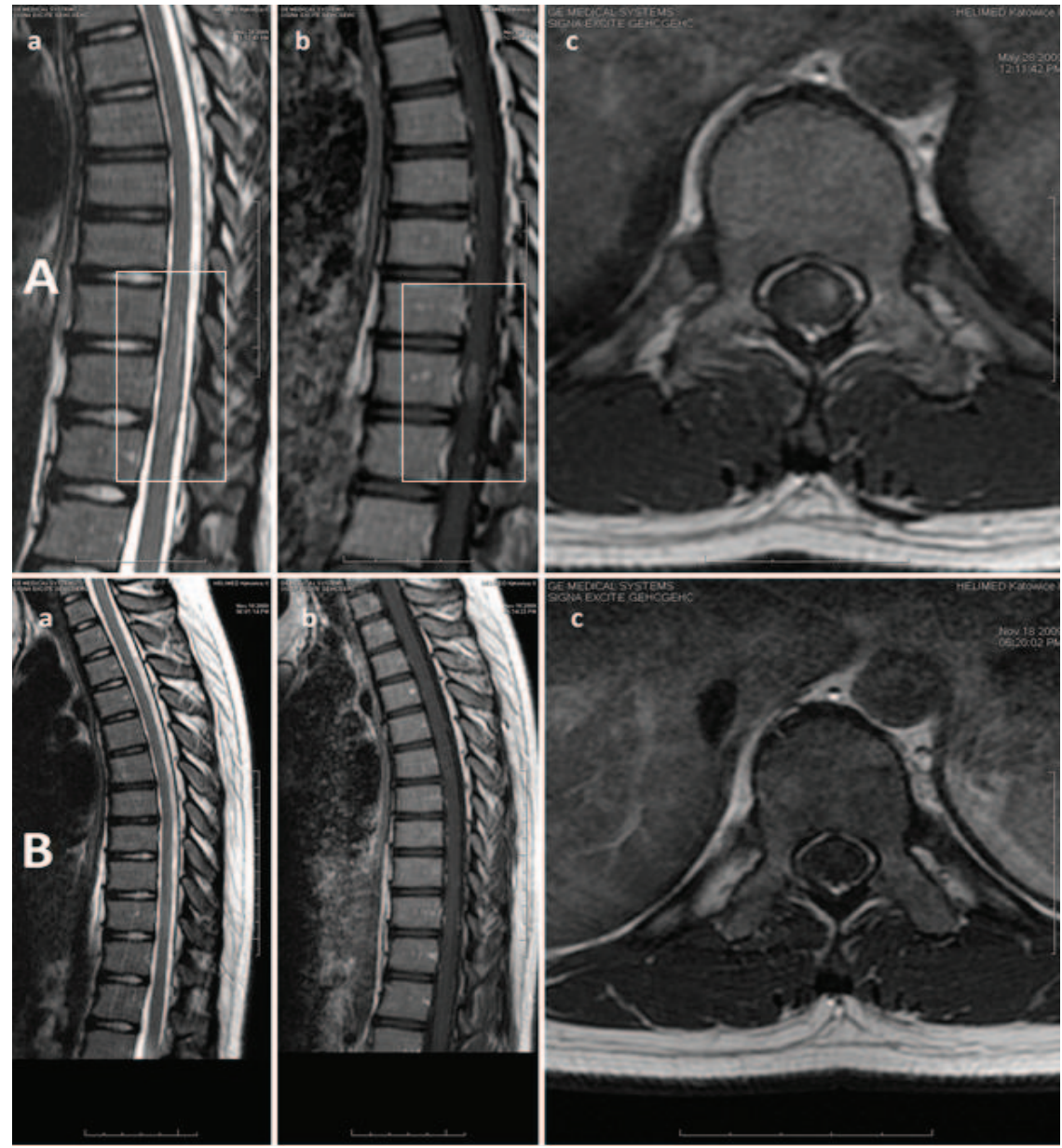

Fig. 1. A: MRI findings in the acute phase of ATM (May, 2009): hiperintense signal changes on T2-weighted image in the thoracic region of the spinal cord (Th9-Th10/Th11) (a) with the contrast enhancement on T1-weighted images in Th10 segment (b,c). B: Spinal MRI showing the evolution of the inflammatory process (November, 2009): Discreet hiperintense lesion on T2-weighted images at the Th9-Th10 level (smaller and less apparent than in the previous MRI examination) (a) with no contrast enhancement on T1-weighted images $(b, c)$.

Ryc. 1. A: Wyniki badania MRI w ostrej fazie ATM (Maj, 2009): obszary hiperintensywne w sekwencji T2 w odcinku piersiowym rdzenia kręgowego (Th9-Th10/Th11) (a) ze wzmocnieniem po podaniu kontrastu w sekwencji T2 w segmencie Th10 (b,c). B: Kontrolne badanie MRI rdzenia ukazuje ewolucję procesu zapalnego (Listopad, 2009): dyskretne, hiperintensywne zmiany widoczne w sekwencji T2 na poziomie Th9-Th10 (mniejsze i słabiej widoczne niż w poprzednim badaniu) (a) bez wzmocnienia po podaniu kontrastu w sekwencji T1 (b,c).
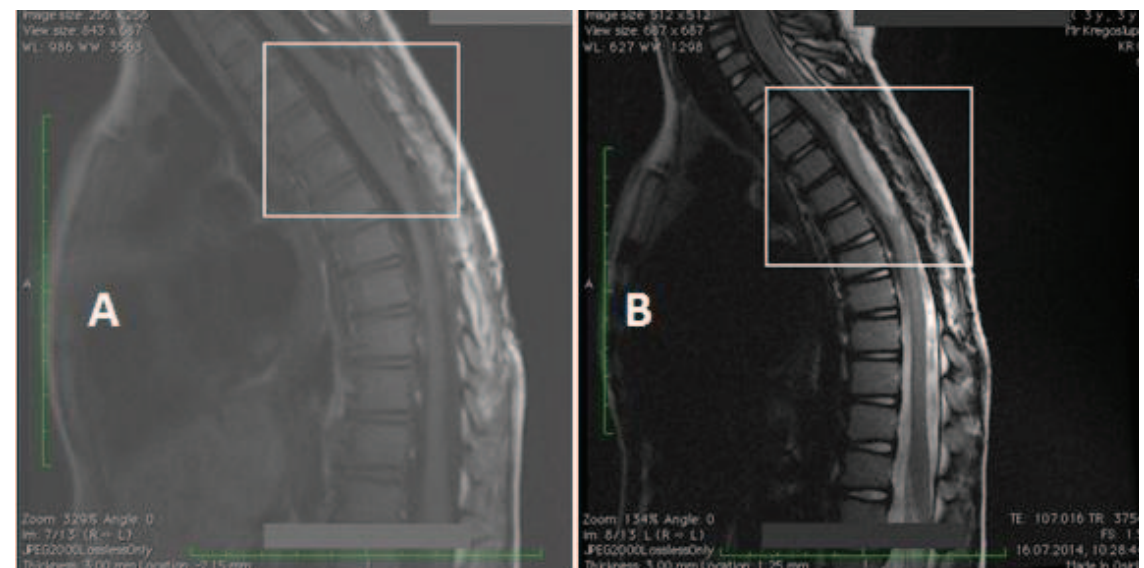

Fig. 2. Spinal MRI findings after partial resection of ISCT in thoracic region of the spinal cord (A: T1-weighted image, B: T2-weighted image). Pathological hiperintense signal changes especially apparent on T2-weighted image (B).

Ryc. 2. Wynik badania MRI rdzenia kręgowego po częściowej resekcji ISCT w odcinku piersiowym rdzenia (A: sekwencja T1, B: sekwencja T2). Patologiczne obszary hiperintensywne widoczne szczególnie w sekwencji T2 (B). 
(54.5\%, 12 children) underwent subtotal resection. Partial resection was performed in the rest of children. No major complications related to the surgical procedures were observed. The length of hospital stay associated with surgical treatment lasted 14 days on average. Six patients required a reoperation due to the tumor recurrence.

\section{HISTOPATHOLOGIC FINDINGS}

Histopathological examination revealed astrocytoma in most children with ISCTs (59\%). Among astrocytoma the pilocytic type was identified in majority of cases $(61.5 \%)$, while the fibrillary type was less common (15.4\%).

Another important group of histopathological results comprised ependymomas (nearly $18.2 \%$ ). The rest of patients were diagnosed with other less common neoplasms (e.g. desmoplatic medulloblastoma, neurenteric cyst). According to the WHO classification system, 52.6\% tumors were grade 1 , about $37 \%$ tumors were grade 2 . One tumor was classified as grade 4 and one as grade 1/2.

\section{FOLLOW UP}

In the follow up most of the children with ATM (7 patients) suffered from a serious gait disturbance (walk on crutches or with a walking frame). Unlike in the group of ISCTs, majority of patients (69\%) were able to walk unassisted. However, decreased muscle strength was present in nearly half of the children. Upper limbs were affected in the same proportion as lower extremities, while in the group of children with ATM the motor dysfunction of the lower extremities was the main persistent symptom in the follow-up.

Sensory malfunction was observed in both ATM and ISCTs patients in similar percentage in the follow up examination (about one-third of the patients).

The sphincters disorders were quite frequent residual symptoms among children with ISCTs (nearly 31\%) unlike in the group of patients with ATM where slight urinary incontinence was observed only in one child.

Moreover, some additional symptoms occurred in patients with ISCTs in the follow up examination. The most common signs were pain as well as spinal cord deformity or instability.

\section{PROGNOSTIC FACTORS}

Sex, age and the mean number of injured segments presented no significant influence on the patients results in the follow up examination. We found no associations between the results of histopathological analysis and the condition of the patients with ISCT in the follow-up.

The mean time between first symptoms and the initial treatment with steroids and/or immunoglobulins did not correlate with the ATM patients` outcome. However, half of the ATM children with no residual symptoms in the follow up examination presented a good response to the initial treatment with steroids ( 2 out of 4 subjects), while in the group of symptomatic patients in the follow-up, the steroid monotherapy in acute phase was sufficient only in 1 out of 7 patients. This difference was statistically significant $\left(p=0.035, \chi^{2}=4.44\right)$.

\section{DISCUSSION}

Our study features clinical courses of 11 children with ATM and 22 children with ISCTs from more than 20400 hospitalizations in the Department of Pediatrics and Developmental Age Neurology and in the Pediatric Neurosurgery Department in 10 years. The number of patients presented in the study is small but comparable to other studies in this field. The small amount of affected children shows how rare the problems of ATM and ISCTs in pediatric patients are.

Some authors describe the characteristic bimodal age distribution of ATM and ISCTs among children with a higher incidence under the age of 3 and in the maturation period $[6,7,13]$. However, most of our patients suffering from ATM were adolescents (13-17 years old) and only one of them was younger than 3 . On the contrary, there was no noticeable age distribution in the group of children with ISCTs.

What is interesting, some authors noticed the seasonal incidence of ATM: an increase of cases in winter with an overlap into late autumn and spring $[6,25,26]$. In our material we also observed that most cases took place in particular seasons - spring and late summer. This tendency might indicate a possible etiological factor of the ATM, especially when comparing it to the seasonal incidence of potentially involved infectious diseases.

In two cases the occurrence of ATM was preceded by a trivial injury the day before. We have found only one reference describing such a correlation. Pidcoc et al established that $13 \%$ of ATM patients had a history of antecedent trauma, usually a fall or a sprain a few days before the onset of acute neurologic symptoms [7]. Also children with ISCTs could complain of symptoms after a mild trauma [19]. However, validity of this relationship is doubtful. The naturally increased motor activity in childhood may result in a higher frequency of small injuries in pediatric patients. On the other hand, a small trauma could be caused by gait instability in the early stages of ATM and ISCTs [8, 19]. What is interesting, some authors report that even a trivial injury may result in spine damage in children. The diagnosis is frequently delayed, especially with a coexistent head injury which may dominate the clinical state [25], for that reason post traumatic changes should be excluded during ATM and ISCTs diagnostic process.

The immunization or allergen immunotherapies are other suspected triggers of ATM. There are many reports of ATM preceded by a vaccination [7, 9, 10, 21, 27]. Similarly, one of our patients was given a compulsory diptheria-tetanus-pertussis + polio vaccination the day before the ATM onset, and the time of the symptoms onset was up to 48 hours after the vaccination.

Paresis, paralysis and sensory loss could occur in both ATM and spinal cord tumor patients. Similarly to other reports, most of the patients with ATM and ISCTs presented a sensory loss and motor disturbances in the initial phase $[6,7,10,13,20,26]$. Therefore, both diseases should be considered when making the diagnosis in children with sensory and motor dysfunctions [8].

Sphincters dysfunction occurred in more than a half of cases in the acute phase of ATM, but was observed only in 
one patient as a residual symptom in the follow up. However, in other studies the data is contrary to our results [8, $13,25]$. Some authors even claimed that impaired sphincters function is the most common long-term symptom following ATM $[6,23]$. In contrast to the ATM, children with ISCTs presented sphincter disorders more often in the follow up examination than during the first hospitalization. Increased sphincter disturbances are also reported by several authors [28, 29].

The MRI examination is a well-established means of diagnosis in patients with ISCTs $[15,17,21,22,30]$ and seems to be quite sensitive in ATM diagnosis in children. In our cases, pathological signals were observed in the spinal MRI in all of the patients. According to available references, the number of patients with abnormalities in spinal MRI ranges from $78 \%$ to $97.4 \%[7,30]$.

Spinal MRI results showed that the cervico-thoracic part of the spinal cord was the most frequently involved region in ATM children. The mean number of the affected segments was 8.64. Similar findings were observed by other authors $[7,10,23,30]$. Long segment involvement seems to be a common radiological feature of ATM in children [8]. However, spinal tumors could also affect many contiguous segments, especially at cervical and thoracic levels [14, 15, 20, 29]. Most of MRI examinations performed in our patients revealed pathological changes mainly in lumbar and cervical/thoracic parts of the spinal cord.

An interesting aspect of this case series is that the level of affected spinal cord segments measured on the spine MRI in the ATM children, did not correlate with all disturbances observed in neurological examination. In our opinion, it is related to the level of motor dysfunction only and it does not correlate with the clinical picture of sensory and vegetative disturbances. Other authors partly agree with this observation $[6,8]$. It could be associated with the fact that the actual inflammatory process in the spinal cord affected more segments than it is shown in MRI.

Due to a high frequency of residual symptoms and a possible risk of disability in the course of ATM and ISCTs many studies focus on the estimation of prognostic factors. There are many suggested predictors. Some authors claim that ATM and ISCTs outcome could be associated with the number of affected segments, patient's age or initial condition [7, 10, 13, 26, 29-31]. However, obtained data has not revealed such correlations.

On the basis of our data, we came to a conclusion that the patient's initial condition and the response to treatment should be also considered as prognostic factors of ATM. The analysis of the ATM therapy in our department revealed that children with milder symptoms, who required only a short or single-drug treatment, presented better outcomes. On the other hand, if the initial condition of the patient was poor, even the intensification of the treatment combined with a multidrug administration did not determine a satisfactory final effect. Moreover, we have noticed that even the use of steroids and immunoglobulin is not sufficient for the patients with more severe initial symptoms. In fact, all of these patients presented some residual symptoms in the follow up examination.
The outcome of this observation confirms that the ATM treatment is still not effective enough, especially in more serious cases. Some authors recommend the use of high-dose steroids due to the high effectiveness in reducing the length of patients ' disability. However, class I evidence for the ATM treatment in pediatric patients has not been established [8].

\section{CONCLUSION}

ATM and ISCTs very often pose a diagnostic challenge - a correct and quick diagnosis could determine the most appropriate treatment and give hope for a good clinical outcome. Magnetic resonance imaging plays an important role in the differential diagnosis of ATM and ISCTs. Sensory loss during the first hospitalization seems to be most common in the group of children with ATM. A poor response to the initial treatment in patients with ATM should be considered as a one of the most important prognostic factors associated with a higher risk of disability at a later time.

\section{REFERENCES}

[1] Sa M. J.: Acute transverse myelitis: a practical reappraisal. Autoimmunity Reviews 2009; 9: 128-131.

[2] Transverse Myelitis Consortium Working Group: Proposed diagnostic criteria and nosology of acute transverse myelitis. Neurology 2002; 59 : 499-505.

[3] Cree B. A. C., Wingerchuk D. M.: Acute transverse myelitis - is the idiopathic form vanishing? Neurology 2005; 65: 1857-1858.

[4] Keer D., Douglas A., Ayetey H. et al.: Immunipathogenesis of acute transverse myelitis. Curr Opin Neurol 2002; 15: 339-347.

[5] Greenberg B. M., Thomas K. P., Krishnan C. et al.: Idiopathic transverse myelitis. Neurology 2007; 68: 1614-1617.

[6] Andronikou S., Albuquerque-Jonathan G., Wilmshurst J. et al.: MRI findings in acute idiopathic transverse myelopathy in children. Pediatr Radiol 2003; 33: 624-629.

[7] Pidcock F. S., Krishnan C., Crawford T. 0. et al.: Acute transverse myelitis in childhood. Neurology 2007; 68: 1474-1480.

[8] Miyazawa R., Ikeuchi Y., Tomomasa T. et al.: Determinants of prognosis of acute transverse myelitis in children. Pediatrics International 2003; 45: 512-516.

[9] Fiszer U.: Ostre poprzeczne zapalenie rdzenia kręgowego. Pol Prz Neurol 2006; 2: 32-36.

[10] Borchers A. T., Gershwin E. M.: Transverse myelitis. Autoimmun Rev 2011; 20: 20.

[11] Kalita J., Misra U. K., Madal S. K.: Prognostic predictors of acute transverse myelitis. Acta Neurol Scand 1998; 98: 60-63.

[12] Seze J., Lanctin C., Lebrun C. et al.: Idiopathic acute transverse myelitis: application of the recent diagnostic criteria. Neurology 2005; 65: 1950-1953.

[13] Defresne P., Hollenberg H., Husson B. et al.: Acute transverse myelitis in children: Clinical course and Prognostic Factors. J Child Neurol 2003; 18 : 401-406.

[14] Kushel Yu. V., Belova Yu. D.: Epidemiology of Pediatric Intramedullary Spinal Cord Tumors. Problems Of Neurosurgery 2014; 6: 30-34.

[15] Dino Samartzis D., Gillis C. C., Shih P. et al.: Intramedullary Spinal Cord Tumors: Part I - Epidemiology, Pathophysiology, and Diagnosis. Global Spine J 2015; 5: 425-435.

[16] Boström A., Kanther N. C., Grote A. et al.: Management and outcome in adult intramedullary spinal cord tumours: a 20 -year single institution experience. BMC Research Notes 2014; 7: 908.

[17] Lee S. M., Cho Y. E., Kwon Y. M.: Neurological Outcome after Surgical Treatment of Intramedullary Spinal Cord Tumors. Korean J Spine 2014; 11: 121-126.

[18] Kumar R., Banerjee S.: Management and functional outcome of intramedullary spinal cord tumors: A prospective clinical study. Asian J Neurosurg 2014; 9: 177-181.

[19] Jallo G. I., Freed D., Epstein F.: Intramedullary spinal cord tumors in children. Childs Nerv Syst 2003; 19: 641-649. 
[20] Gwi H. C., Jae K. O., Tae Y. K. et al.: The clinical features and surgical outcomes of pediatric patients with primary spinal cord tumor. Childs Nerv Syst 2012; 28: 897-904.

[21] Choudhri A. F., Whitehead M. T., Klimo P. et al.: Diffusion tensor imaging to guide surgical planning in intramedullary spinal cord tumors in children. Neuroradiology 2014; 56: 169-174.

[22] Takami T., Naito K., Yamagata T. et al.: Surgical management of spinal intramedullary tumors: radical and safe strategy for benign tumors. Neurol Med Chir 2015; 55: 317-327.

[23] Tobias M. E., McGirt M. J., Chaichana K. L. et al.: Surgical management of long intramedullary spinal cord tumors. Childs Nerv Syst 2008; 24: 219-223.

[24] Whittle E., Roberton N. R.: Transverse myelitis after diphteria, tetanus, and polio immunisation. BMJ 1977; 1: 1450.

[25] de Amoreira Gepp R., Nadal L. G.: Spinal cord trauma in children under 10 years of age: clinical characteristics and prevention. Childs Nerv Syst 2012; 28: 1919-1924.
[26] Alvarenga M. P., Thuler L. C. S., Neto S. P. et al.: The clinical course of idiopathic acute transverse myelitis in patients from Rio de Janeiro. J Neurol 2010; 257: 992-998.

[27] Giu L., Kangning C., Zhang Y.: Acute transverse myelitis following vaccination against H1N1 influenza: a case report. Int J Clin Exp Pathol 2011; 4: 312-314.

[28] Mcgirt M. J., Chaichana K. L., Atiba A. et al.: Resection of intramedullary spinal cord tumors in children: assessment of long-term motor and sensory deficits. J Neurosurg Pediatrics 2008; 1: 63-67.

[29] Garcés-Ambrossi G. L., McGirt M. J., Mehta V. A. et al.: Factors associated with progression-free survival and long-term neurological outcome after resection of intramedullary spinal cord tumors: analysis of 101 consecutive cases. J Neurosurg Spine 2009; 11: 591-599.

[30] Alper G., Petropoulou K. A., Fitz C. R. et al.: Idiopathic acute transverse myelitis in children: An analysis and discussion of MRI findings. Mult Scler 2011; 17: 74-80.

[31] Ahmed R., Menezes A. H., Awe 0. 0. et al.: Long-term disease and neurological outcomes in patients with pediatric intramedullary spinal cord tumors. J Neurosurg Pediatrics 2014; 13: 600-612. 
